\title{
Ignorance of regulation as one of the causes of head of regions corruption in Indonesia
}

\author{
Teguh Kurniawan \\ Department of Public Administration \\ Faculty of Administrative Science, \\ Universitas Indonesia \\ Depok, Indonesia \\ teguh.kurniawan@ui.ac.id
}

\author{
Eko Prasojo \\ Department of Public Administration \\ Faculty of Administrative Science, \\ Universitas Indonesia \\ Depok, Indonesia \\ prasojo1@ui.ac.id
}

\author{
Gunadi \\ Department of Fiscal Administration \\ Faculty of Administrative Science, \\ Universitas Indonesia \\ Depok, Indonesia \\ triguna.gunadi@gmail.com
}

\begin{abstract}
Corruption is a major problem faced by the Indonesian people, including those occurring in the Regional Government. To adequately address the issue of corruption, the understanding of the causes of corruption needs to be given attention so that efforts to prevent and eradicate corruption can be adjusted to the root of the problem. From the search results to the various literature, it can be seen that in essence, corruption is caused by some factors that either contribute directly or indirectly. Also, factors causing corruption can also be distinguished between factors related to individual characteristics as well as structural influences. This study wants to know whether ignorance or lack of understanding of regulation can be constructed as the cause of corruption by the Head of Region in Indonesia. This research uses constructivist paradigm and use qualitative research method with a case study and done normatively. Based on the results of the study, ignorance or lack of understanding of regulation can be constructed as the cause of corruption by the Head of Region in Indonesia. Ignorance of regulation can be categorized as a cause of corruption in the context of Indonesia and other developing countries.
\end{abstract}

Keywords-causes of corruption; head of regions; ignorance of regulation

\section{INTRODUCTION}

Corruption in Indonesia is still a major problem including what happened in the Regional Government. The magnitude of corruption problems in Indonesia can be seen from among the cases handled by some law enforcers including the Corruption Eradication Commission (KPK). Based on data released by the KPK, from 2004 to June 2017, there were 670 cases of corruption which is handled by the KPK. Of these, 78 cases involving the Head of Region both the Governor and the Regent / Mayor [1]. Also, some surveys, both domestic and foreign, always show a high rate of corruption in Indonesia. A recent survey conducted by Center for Strategic and International Studies and Management Systems International published in July 2016 shows that $66.4 \%$ of respondents have seen an increase in the number of corruption in the past two years [2]. This condition is of course very alarming and needs to get serious attention from all components of the nation.

Efforts to solve corruption problems in Indonesia, including those conducted by the Head of Region, of course, cannot be separated from the causes of corruption. Therefore, efforts to determine the causes of corruption is one of the important efforts in solving corruption problems. By knowing the causes of this corruption, it is expected to lead us to the best possible efforts to prevent or combat corruption based on the cause.

Related causes of corruption, based on information from various literature can be seen that in essence, corruption caused by some factors either contribute directly or indirectly. Also, factors causing corruption can also be distinguished between factors related to individual characteristics as well as structural influences. An understanding of the causes of corruption caused by direct and indirect factors can be seen in Tanzi [3]. According to Tanzi, there are at least six direct causes of corruption: (1) regulation and authorization, (2) taxation, (3) expenditure / budget policy, (4) provision of goods and services below market price, (5) other discretionary policies, and (6) the financing of political parties. Meanwhile, the indirect cause of corruption consists of at least six factors: (1) the quality of the bureaucracy, (2) the salary in the public sector, (3) the punishment system, (4) the supervision of institutions, (5) the transparency of rules, laws and processes, and (6) the example of the leader. The explanation of the causes of corruption associated with individual characteristics and structural influences can be seen in the writings of Nas, Price, and Weber [4]. They argue that corruption seen from individual characteristics occurs when an individual is greedy or unable to resist temptation, is weak and has no ethics as a public official. While the causes of corruption from the structural side are caused by three things: (1) failed bureaucracy or organization, (2) quality of community involvement and (3) harmony of the legal system with public demand.

In the context of corruption cases in Indonesia, some parties argue that the lack of understanding of officials is one cause of corruption. President Susilo Bambang Yudhoyono (SBY) in the ninth anniversary of Anti-Corruption Day and World Human Rights Day at the Presidential Palace on December 10, 2012 discusses two types of corruption which one of them is due to the lack of understanding of officials against regulation [5]. The lack of understanding of the Head of Region against the regulation is also indicated as one of the factors causing the corruption of the Head of Region according to the results of a 
study from the Center for Research and Development of Supervision, the Financial and Development Supervisory Agency (BPKP) conducted in 2016 [6].

Departure from the problematic situation, hence this research wants to know whether ignorance or lack of understanding of regulation can be constructed as the cause of corruption by Head of Region in Indonesia. Through this research is expected to enrich the theory of corruption, especially related to the causes of corruption so that it can contribute to the relevant and contextual causal factors with the conditions of developing countries such as Indonesia.

\section{METHOD}

This research is based largely on constructivist paradigms that view knowledge as a social construction and may change depending on circumstances. Through this research, researchers try to understand whether the ignorance or lack of understanding of the Head of Regions against the regulation can be constructed as one of the causes of corruption by the Head of Region. Understanding is done by studying how corruption cases conducted by the Head of Region occurs through an understanding of social and historical reality that covers it and relate it to various applicable laws and regulations. Thus, when referring to the opinion Irawan [7], then in this study researchers try to "catch" what is in the case of corruption Head of Region and then construct into a concept of science.

To be able to answer the research question, this research used qualitative research method with a case study and done normatively. Normative assessment is used because in exploring and identifying the social and historical realities that lead to corruption by the Head of Region, researchers rely more heavily on the Court's Decision which has had a permanent legal force (inkracht). The case study was chosen because it is considered to help researchers in exploring the process of the occurrence of corruption by the Head of Region. Through this case study method, the researcher conducted an in-depth review of five cases of corruption by the Head of Region handled by the KPK and is a case that already has a permanent legal force (inkracht). The determination of a case study is conducted purposively using two main criteria in determining the selected case study: (1) information-rich (containing sufficient information for understanding the research problem); and (2) affordable (relatively easy to reach and open for examination, fewer files, affordable if accessed).

This research uses the qualitative method so that the tool used in this research is research tool commonly used in qualitative research that is: documents, either policy document or other document and depth interview. The data collection technique used is a combination of various techniques, namely in-depth interviews using unstructured questions, assessment of relevant documents such as court decision documents that have both inkracht and other related supporting documents such as regulations or news from various mass media related to the case, and by analyzing the contents of various documents of court decisions, policy documents, legislation or news from the mass media.

\section{RESULTS}

One important factor affecting the successful implementation of a policy including regulation is the level of understanding and knowledge of policy implementers on policy. In this regard, Ali [8] show that the lack of understanding of education managers has led to severe consequences in the implementation of education policies and reforms in Pakistan. Departing from this understanding, the results of this study indicate that in various cases of corruption Head of Region who became a case study, there have been violations of various laws and regulations that make the Head of Regions then convicted.

Related to the violation of various laws and regulations by the Head of Regions, based on the results of in-depth interviews that researchers conducted on a number of informants, this study found that 8 out of 12 informants expressed ignorance of regulation as one of the things that can be constructed as the cause the occurrence of corruption by the Head of Regions. The following in-depth interview quotes can provide insight into the number of officials or Head of Regions who has been exposed to criminal cases as a result of their ignorance of the various laws and regulations.

"... The second category, the lack of understanding, because the head of the region process is a political process. This political process many of them are not experienced in the field of bureaucracy. Financial administration, all that kind of rules dozens of it, and still changing so that they do not know the rules. While one such rule has since been enacted since it was announced it is considered everyone knows. So, in some cases, we find the lack of capacity of the regional head. Lack of capacity is then in the implementation there are two more categorizations. The first category, utilized by his subordinates who play. He did not know his subordinates were playing. The second category, both did not know that it was later against the law and harm the state." [F. Wibisono, personal communication, August 6, 2015]

"... I tell you that one of the things that we debate in the law but not included in this bill is about how this government administration law can protect clean government officials. .... An example is when a government official is a nice person, clean, he is consistent. But he does not know the administrative issues. The official was not too familiar with administrative, technical matters. But he has principles. The principle is that he has high integrity, does not abuse of authority, does not benefit himself, his intention is solely to make improvements, breakthroughs. It turned out that from these improvements there was an administrative mistake that at the beginning of his work he was not minded until there, but later when examined found administrative errors." [M. G. Hamzah, personal communication, June $12,2015]$

"By authority, indeed the Head of Region now has a high authority. The greater the power, the higher the potential abuse. Whether intentional or not. Sometimes 
there are also problems related to abuse of authority arising from the ignorance of officials. But these are not many, many of which are deliberately seeking personal gain." [B. T. Purnama, written communication, July 31, 2015]

"Indeed, some things may concern two things. First, the corruption was done with deliberate intent to seek wealth, so no apology for the case, because he preyed on. But there is a second type where corruption is legally unlawful, because of ignorance or the position of him as an official or whoever becomes an official, he may be exposed to it because it is attached to his post. Well this, so this should be categorized from these two things .... " [J. B. Kristiadi, personal communication, June 18, 2015]

"Yeah exactly. So, if they want to. It's just we imagine, sorry for that. There is a Regent that was former of a pedicab driver, how he knows about it. Politicians, you will not know about it. Because their knowledge is limited. I'm not underestimating the region, but they are from people who do not know, are not competent in the field, suddenly came up ... " [H. Subiyantoro, personal communication, July 30, 2015]

"... But in reality, there are those who want to give the disposition. He probably did not understand the rules. If he understands the rule that he cannot manage it. " [B. Pamungkas, personal communication, June 18, 2015]

"... So back again to the discretion, the discretion depends on the man. Who holds the discretion. Knowledge, experience, integrity is very dominant in taking discretion. And more importantly, he's obeying the rules, straight. Yes, indeed it means that discretion outside the rules. But the discretion should be justified to the extent of propriety, decency, worthiness. Cannot be arbitrary, and of course, discretion should not be flavored with interests. There should be no conflict of interest. If there is a conflict of interest it is not a discretion anymore, but arbitrary." [R. Atmasasmita, personal communication, July 2, 2015]

"That's right, from about one to ten, about the one being sacrificed like that I see it only one or two at most. The rest are criminals, and there is a tendency for them to take refuge there." [D. Fariz, personal communication, June 26, 2015]

The opinions of the above eight informants can illustrate a very worrying condition where there are still many Heads of Regions or other officials who do not have sufficient knowledge of the administration of government as a result of their background before taking office. This condition, of course, needs to get special attention from the government so that it can minimize the number of Heads of Regions affected by the problem as a result of their lack of understanding or ignorance of various existing laws and regulations.

Facts about the ignorance of regulation can also be found from the analysis that the researchers conducted on court decisions of Head of Regions who became case studies, especially by the statements of the Heads of Regions given when they went to trial. Of the five Heads of Region who became the case study, two of them (Ismunarso and Arwin AS) is the Head of Region which, according to the researchers can be categorized entangled corruption because of their ignorance of the laws and regulations that violated. While the other three Head of Region (Abdullah Puteh, Mochtar Mohamad, and Amran A Batalipu) is the Head of Region which according to the researcher can be categorized knowing the regulation but deliberately do it.

Based on some statements from the Heads of Regions in their trials, the researchers categorize that the acts committed by Ismunarso and Arwin AS occurred due to their ignorance of some laws and regulations. In the case of Ismunarso, he has even consulted the Head of the Regional Supervisory Board (Bawasda), and according to the Head of Bawasda, the placement of funds for deposits at Bank Negara Indonesia (BNI) does not violate the rules because it is possible by Ministry of Home Affairs Decree 29/2002. However, based on the consideration of the panel of judges, Ismunarso is considered proven to have violated Article 41 paragraph (5) of Law 1/2004 because of the placement of regional government funds to private parties that are not done through the issuance of Regional Regulation. Thus, it can be seen that there is inadequate understanding of Ismunarso and Head of Bawasda regarding various laws and regulations.

Meanwhile, in the Arwin AS case also shows his ignorance of some laws and regulations governing the issuance of a license for the utilization of timber forest products in plantation forests (IUPHHK-HT) so that the issuance of permits contradicts some provisions in Ministry of Forestry Decree 10.1 / Kpts-II / 2000 and Ministry of Forestry Decree 21 / Kpts-II / 2001. Based on his statement, Arwin AS claimed to know Ministry of Forestry Decree 10.1 / Kpts-II / 2000 when inspected in Riau Regional Police Office. Arwin AS also claimed not to know the administrative process in the issuance of IUPHHK-HT. Therefore he was guided by the study of Forestry Agency, and in fact, the study of the Forestry Agency did not provide information about various things that are inconsistent with some laws and regulations. Thus, it can be seen the ignorance of Arwin AS against some laws and regulations when issuing permits IUPHHK-HT for some companies.

Based on the opinion of most of the informants and the statement of the Head of Region in the trial, this research finds the factor of ignorance of regulation as one of the causes of corruption by the Head of Region in Indonesia. Ignorance is according to some informants and the results of the researcher's analysis of the statements of the Heads of Region in the trial, only occurred in a small part of the Head of Region. While many of the Heads of Regions who commit a corruption know the existence of regulation proved violated.

\section{DISCUSSION}

The findings of this study that the factor of ignorance of regulation as one of the causes of corruption by the Head of Region in Indonesia is an important finding when associated 
with the existence of corruption theory, especially when associated with the context of corruption that occurred in Indonesia and other developing countries. Based on the research results of researchers on the various literature of corruption, especially developed by experts who come from developed countries, no theory directly mentions the factors ignorance of regulation as one cause of corruption. The theory suggests that the cause of corruption, even if it is related to regulation, is as a result of cultural factors as suggested by Holmes cited by Voskanyan [9]. According to Holmes, one of the cultural factors as the cause of corruption is the result of the weak tradition in the rule of law and the low level of respect for the law. This means that according to Holmes, people know the rules but do not respect it. So not for ignorance.

Thus, ignorance of regulation can be categorized as a factor causing corruption in the context of Indonesia and other developing countries, since the researchers also found the existence of corruption literature written by authors from developing countries mentioning ignorance of this regulation. For example, in Singh [10] which reveals that one of the main causes of corruption in modern India is the lack of awareness or ignorance of rules and laws. When linked to the causes of corruption by indirect and indirect causes as proposed by Tanzi [3], as well as individual and structural factors as proposed by Nas, Price, and Weber [4], the factor of ignorance of regulation may contribute to both theories. Factors of ignorance of regulation can be categorized as indirect and individual causes. Indirectly related to the quality of the bureaucracy to strengthen Tanzi's opinion, while individually can add opinions from Nas, Price, and Weber.

About the factor of ignorance of regulation as one of the causes of corruption by the Head of Region in Indonesia, this research proposes activities to increase the capacity of the Head of Region, especially the newly elected Head of Region. Through this activity, the newly elected Heads of Regions will be provided with an understanding of the various laws and regulations, the understanding of authority limits, and experiences from other experienced Heads of Region. This proposal was also raised by a resource person who had served as Director of Prosecution of KPK as the following quotation.

"... Well for the second problem of capacity, for the first group lack of capacity, of course, the lack of it must be addressed. Means a Head of Region should be given sufficient materials debriefing about the processes of government, because its capacity perforated ...." [F. Wibisono, personal communication, August 6, 2015]

Related to the increase of knowledge and understanding of the Head of Region, then one of the most important legislation that needs to be understood is Law 30/2014 which in the view of the researcher can be felt to help to protect the officers or Head of Region affected by the problem as a result of their ignorance of regulation. Law 30/2014 also stresses the importance of testing for abuse of authority. Through this test can be seen where the intentional or unintentional act due to ignorance of a Head of Region. Support for the existence of the Law 30/2014 is also raised by one of the informants who are Experts in Criminal Law as the following quotation.
"Be careful. So, in other words in Government Administration law is already the way, have advanced there. It's the only main task and function. Now there are parameters and benchmarks. Forcing the prosecutor to study the law of the Government Administration ...." [R. Atmasasmita, personal communication, July 2, 2015]

Regarding capacity building efforts for the Head of Region, if we browse through the internet, it can be seen that the Ministry of Home Affairs has made training efforts to the Head of Region [11]. However, this effort is relatively new and only implemented for two times. Also, KPK has also conducted training to the Head of Region through cooperation with Central Java Provincial Government [12]. This activity is also a relatively new activity implemented. Thus, the proposal on capacity building for the Head of Region is still very relevant to be done.

In addition to training, capacity building efforts from the Head of Region should also be supported by the creation of a database that can be used by the Head of Region in policymaking. With this database, the Head of Region can know what rules are already available and must be followed, as well as various other information needed in the process of issuing permits. Also, through this database can also monitor the various policies made by the Head of Region so that it can be a means for conducting supervision on the policy of the Head of Region, including regarding licensing.

Other measures that can be taken to reduce ignorance of regulation are to optimize the role of law enforcement officers such as the Attorney and KPK and the Government Internal Supervisory Apparatus (APIP) in providing consultations to the Head of Region before making policy. This effort is in line with the opinion of an informant who came from the Attorney General and has served as Director of Prosecution of KPK as the following quotation.

"Among other things. So, this is not just proposed but it has been built, and we have done, now is increasing and growing. First is the prosecutor's office providing legal consultations. So, if they lack capacity, if there is uncertainty about the legal aspect, they ask the attorney. The prosecutor's office installed prosecutors, civil and criminal lawyers. If there is a free legal consultation, the Attorney General Office establishes a free consultation service unit. Then if they need a legal opinion, they can get a legal opinion from prosecutors. The Prosecutor's Office in West Java cooperates with BPKP. If the apparatus is no doubt about the financial aspect, we suggest that we encourage the opinion of BPKP. We cooperate with BPKP so that BPKP will assist each request, so in West Java region for the prosecutor's office with BPKP this is the demand for a legal opinion is big enough, then the legal consultation requested is usually if necessary we accompany. So, there is legal counseling. Requests for system improvement from BPKP were very much requested from the Heads of Region. Instead, they are subject to legal issues, where the law is indiscriminate and 
legal processes all. So, the strategy that we apply the law firm. The law is objective, at the same time we provide legal assistance and technical assistance together with BPKP. " [F. Wibisono, personal communication, August 6, 2015]

About APIP's involvement in the provision of consultations, by looking at the Ismunarso case before placement of regional government funds for Deposit has requested APIP advice, it is necessary to ensure competence and professionalism from APIP first. So APIP will not give inappropriate advice as happened in Ismunarso case.

\section{CONCLUSIONS}

Based on the findings and discussion, it can be concluded that ignorance or lack of understanding of regulation can be constructed as the cause of corruption by the Head of Region in Indonesia. Ignorance of regulation can be categorized as a cause of corruption in the context of Indonesia and other developing countries, as there is also corruption literature written by authors from developing countries mentioning ignorance of regulation as the cause of corruption. Factors of ignorance of regulation may contribute to the corruptioncausing theory of Tanzi [2] on the direct and indirect causal factors and the corruption-causing theories of Nas, Price, and Weber [3] on both individual and structural factors. Factors of ignorance of regulation can be categorized as indirect and individual causes. To overcome the problem of ignorance of regulation, this research proposes the existence of activities to increase the capacity of the Head of Region, especially the newly elected Head of Region. Through this activity, the newly elected Heads of Regions will be provided with an understanding of the various laws and regulations, the understanding of authority limits, and experiences from other experienced Heads of Region.

\section{REFERENCES}

[1] “TPK Berdasarkan Profesi/Jabatan,” Anti Corruption Clearing House Komisi Pemberantasan Korupsi. [Online]. Available: https://acch.kpk.go.id/id/statistik/tindak-pidana-korupsi/tpk-berdasarkanprofesi-jabatan. [Accessed: 15-Sep-2017].

[2] CSIS, and MSI, Persepsi Masyarakat terhadap Fenomena Korupsi di Indonesia, Jakarta: USAID, CSIS, and MSI, 2016.

[3] V. Tanzi, "Corruption Around the World: Causes, Consequences, Scope, and Cures," IMF Staff Papers, vol. 45, pp. 559-594, May 1998.

[4] T.F. Nas, A.C. Price, and C.T. Weber, "A Policy-Oriented Theory of Corruption," The American Political Science Review, vol. 80, pp. 107119, March 1986.

[5] K. C. Media, "Presiden: Banyak Korupsi karena Pejabat Tak Paham," KOMPAS.com. [Online]. Available: http://nasional.kompas.com/read/2012/12/10/1305004/Presiden.Banyak. Korupsi.karena.Pejabat.Tak.Paham. [Accessed: 15-Sep-2017].

[6] "Faktor-Faktor Penyebab Kepala Daerah Korupsi," Badan Pengawasan Keuangan dan Pembangunan. [Online]. Available: http://www.bpkp.go.id/puslitbangwas/konten/2674/16.050-FaktorFaktor-Penyebab-Kepala-Daerah-Korupsi. [Accessed: 15-Sep-2017].

[7] P. Irawan, Penelitian Kualitatif \& Kuantitatif untuk Ilmu-Ilmu Sosial, Depok: Departemen Ilmu Administrasi FISIP UI, 2006.

[8] S. Ali, "Deficient Policy Communication Deficient Outcomes Capacity Building Policy under Education Reforms in Sindh, Pakistan," Bulletin of Education and Research, vol. 33, pp. 1-19, June 2011.

[9] F. Voskanyan, "A Study of the Effects of Corruption on Economic and Political Development of Armenia," M.S. thesis, Grad. School of Pol. Sci. and Intl. Affairs American Univ. of Armenia, Yerevan, Armenia, 2000.

[10] D. Singh, "Different Dimensions of Corruption in India: Some Suggestions for Prevention," Research Journal of Philosophy and Social Sciences, vol. 42, pp. 1-6, March 2016.

[11] "Menkopolhukam Apresiasi Pelatihan Kepala Daerah di Kemendagri," Kementerian Dalam Negeri. [Online]. Available: http://www.kemendagri.go.id/news/2016/05/26/menkopolhukamapresiasi-pelatihan-kepala-daerah-di-kemendagri. [Accessed: 15-Sep2017].

[12] “17 Kepala Daerah Jateng Pelatihan Anti Korupsi," HarianTerbit.com. [Online]. Available: http://nasional.harianterbit.com/nasional/2016/03/23/58816/0/25/17Kepala-Daerah-Jateng-Pelatihan-Anti-Korupsi. [Accessed: 15-Sep2017]. 